\title{
Studies on Gonadosomatic index (GSI) \& sex ratio of Sind sardine fish, Sardinella sindensis (day, 1878) (family: Clupeidae) of Karachi coast, Pakistan
}

\author{
M. Usman Ali Hashmi, Amtyaz, M. Zaheer Khan , M. Atiqullah Khan \\ Dept. of Zoology, Dehli Govt. Science College, Hussainabad, Karachi \\ Dept. of Zoology, Sir Syed Govt. Girls College Nazimabad, Karachi \\ Dept. of Zoology, University of Karachi \\ Dept. of Zoology, University of Karachi \\ *Corresponding author E-mail: hashmiusman39@gmail.com
}

\begin{abstract}
The sex ratio \& Gonadosomatic index of sind sardine, Sardinella sindensis (Day, 1878) of Karachi coast, Pakistan were investigated. Sardinella sindensis had sex ratio of 1: 1.25 (male to female). The difference in sex ratio was not significantly different $(\mathrm{p}>0.05)$ from the expected theoretically 1: 1 distribution except April 2002.

The highest Gonadosomatic index value in males during June - August were 3.813 to 4.078, while in females the high values during June - August were found to be 3.157 to 5.616, which suggested the spawning period. The highest GSI value in males were 2.548 to 2.711 in size groups of $170-199 \mathrm{Mm}$ and the lowest GSI value were $0.627-0.746$ recorded in $110-129 \mathrm{Mm}$, while in females at high values were 3.769 to 4.550 in $180-209 \mathrm{Mm}$ Size groups and the lowest GSI values were 0.686 to 1.064 in $100-139 \mathrm{Mm}$ size groups. The results will increase our knowledge of reproductive biology of Sardinella sindensis which is relevant for fisheries and aquaculture management as well as breeding programmes.
\end{abstract}

Keywords: Sex ratio, gonadosomatic index, sardinella sindensis.

\section{Introduction}

Commercial quantities of large numbers of finfish and shellfish are present in the Pakistani coastal waters [1]. The Striped piggy grunt, Sardinella sindensis is among the fish species of great economic importance in the Pakistani coastal waters. It belongs to the family Clupeidae and can be found in pelagic-neritic; depth range 0 - $50 \mathrm{~m}$ of Western Indian Ocean: Arabian Sea, from Gulf of Aden to the Persian Gulf and Bombay (Fig. 05). Gonadosomatic index which is an index of gonad size relative to fish size is a good indicator of gonadal development in fish [2]. The percentage of body weight of fish that is used for production of eggs is determined by the gonadosomatic index. The percentage of body weight of fish that is used for production of eggs is determined by the gonadosomatic index. Sex ratio studies provide information on the representation of male and female fish present in a population. It states the proportion of male to female fish in a population and indicates the dominance of sex of fish species in a given population. Sex ratio also constitutes basic information necessary for the assessment of the potential of fish reproduction and stock size estimation in fish population [3]. In estimating the reproductive potential of fish, information on sex ratio of fish can be included to determine female spawning biomass.

Information on the reproductive biology of some other economically important fishes of the Indo-Pak and Arabian Gulf coasts has been reported by some authors ([4], [5], [6], [7], [8], [9], [10], [11], [12], [13], [14]). There is paucity of information on the study of reproductive biology of the Sind Sardine, Sardinella sindensis in the Karachi coast. However some works are available on reproductive biology, fecundity, maturation, spawning and sex ratio of some other important Sardine species ([15], [16], [17], [18], [19], [20], [21], and [22]). The reproductive biology of Sardinella sindensis has not been widely reported in literature. The aim of this study was to investigate the gonadosomatic index and sex ratio, which are some aspects of the reproductive biology of Sardinella sindensis of the Karachi coast, Pakistan. It is hoped that the information obtained from this study will contribute to our knowledge of the reproductive biology of Sardinella sindensis and will be useful for fisheries and aquaculture production. 


\section{Materials and methods}

\subsection{Study area}

The Karachi coast was the study area for this research. The Karachi coastline is between latitude $24^{\circ} 53$ ' $\mathrm{N}$ and longitude $67^{\circ} 00^{\prime} \mathrm{E}$ and lies in the Northern boundary of Arabian Sea.

\subsection{Collection of specimens and sampling}

Samples of Sardinella sindensis were collected fortnightly (A total of 32 collections) from fish harbors of West Wharf and Korangi Creek of Karachi coast. The specimens were collected during January 2001 - April 2002. The fish was identified by using [23] (FAO fish identification manuals). Simple random sampling technique was used [24]. A total of 419 samples collected during the study period. The samples were transported to the laboratory and preserved in a deep freezer at $-20^{\circ} \mathrm{C}$ until examination and analysis.

\subsection{Body measurements}

The specimens were brought out of the deep freezer and allowed to thaw and the body length and weight were measured. Total and standard lengths were measured using a one-meter measuring board graduated in $\mathrm{cm}$. The fish was wiped with a dry napkin before weighing and body weight and ovary weight were measured using a weighing balance (Sartorius model).

\subsection{Sex ratio}

Each specimen was dissected and the gonads were removed. The sex of each specimen was identified by examination of the gonads. The proportion of the two sexes relative to one another was used to calculate the sex ratio.

\subsection{Gonad somatic index}

The Gonad somatic index was calculated according to Strum [25] as follows:

GSI = Weight of gonad x 100

Weight of fish

\section{Results}

A total of 199 males and 220 females were observed out of 419 samples examined. The sex ratio was 1:1.25 (male to female). The difference in sex ratio was not significant ( $p>0.05)$ (Tab. $01 \& 02$; Fig. $01 \& 02$ ).

The GSI values in males during August - November were 3.109 to 5.630 after which the values decreased slowly reaching to minimum in July(1.072), while in females the high values during August - December were found to be 3.542 to 6.679. This suggests that male and female gonads mature during August - December, the peak value being in October (Table $02 \& 03) \&$ (Fig. 03).

The highest Gonad somatic index value in males during June - August were 3.813 to 4.078, while in females the high values during June - August were found to be 3.157 to 5.616, which suggested the spawning period. The highest GSI value in males were 2.548 to 2.711 in size groups of $170-199 \mathrm{Mm}$ and the lowest GSI value were $0.627-0.746$ recorded in $110-129 \mathrm{Mm}$, while in females at high values were 3.769 to 4.550 in $180-209 \mathrm{Mm}$ Size groups and the lowest GSI values were 0.686 to 1.064 in $100-139 \mathrm{Mm}$ size groups (Table 05 \& 06) \& (Fig. 04).

The GSI value in males during June - August were highest, after which the values decreased slowly reaching to minimum in February (0.609) and March (0.602), while in females the high values during June - August. After which the values decreased slowly reaching to minimum in February (1.350) \& March (0.840). This suggests that male and female gonads mature during June - August and these are the peak seasons for spawning (Table 03 \& 04) \& (Figure $03)$.

The highest gonad somatic index value in males were 2.711 (190-199 Mm of size group) and the lowest GSI value 0.627 (120-129 Mm of size group) were recorded, while in females the high value was 4.550 (190-199 Mm of size group) and the lowest GSI value were 0.686 (120-129 Mm of size group) (Table 05 \& 06) \& (Figure 03 \& 04). 
Table 1: Sex ratio (male: female) of s. sindensis in different months

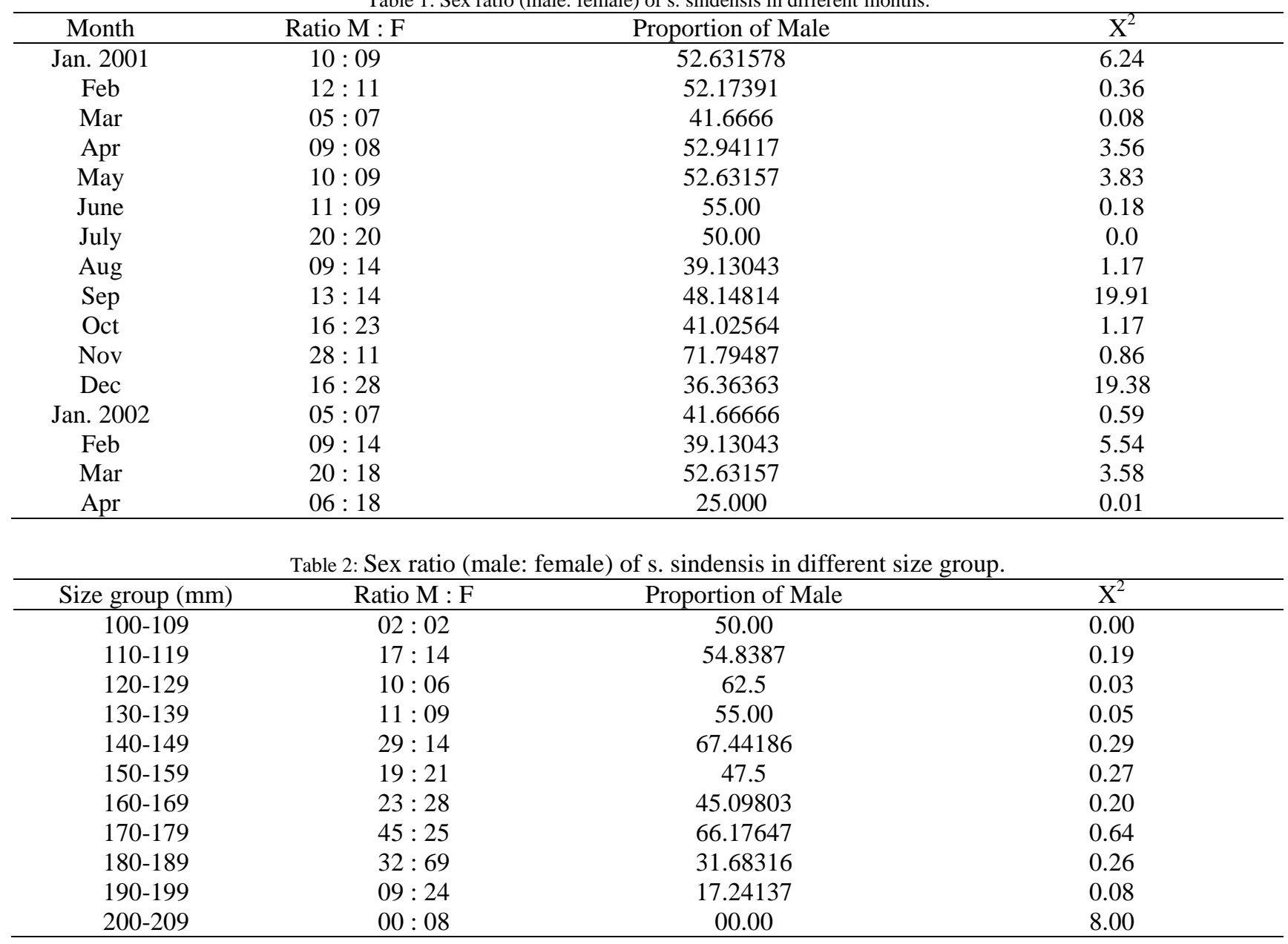

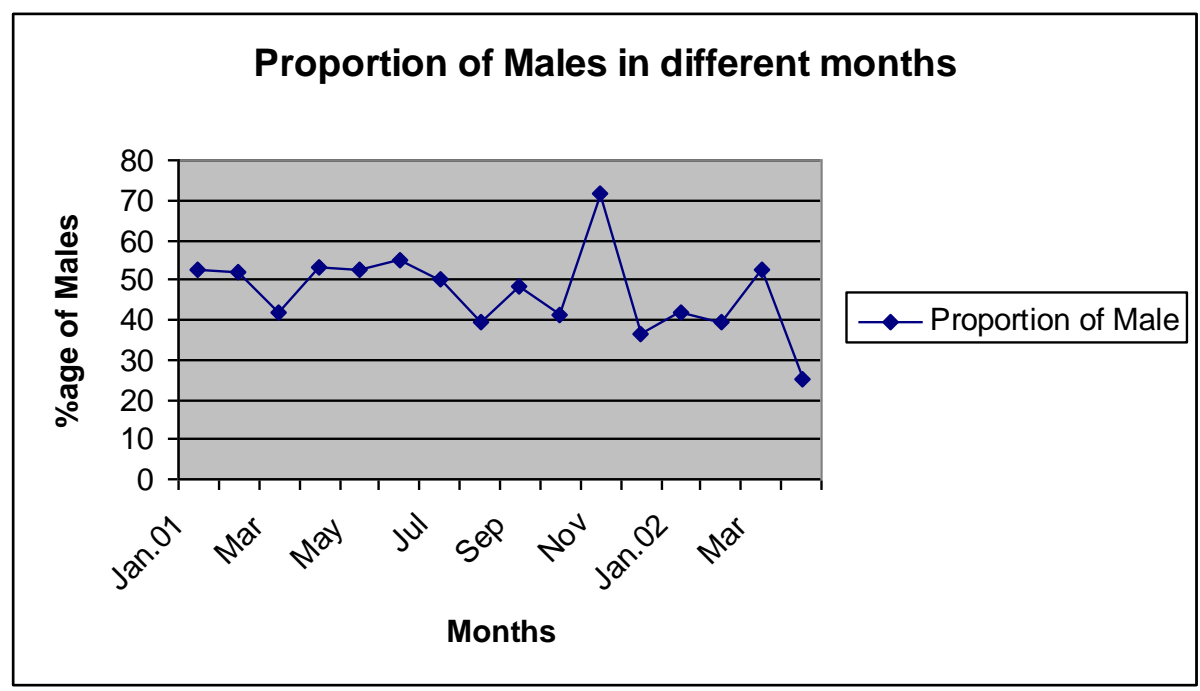

Fig. 1: Proportion of Males in different months. 


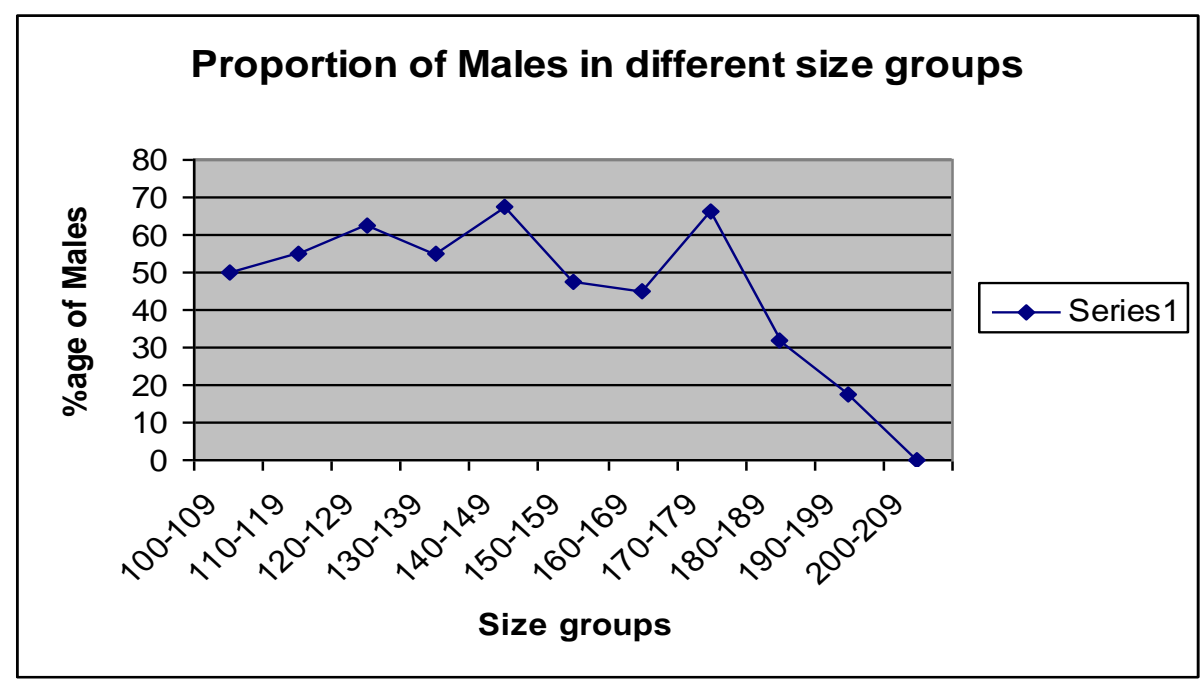

Fig. 2: Proportion of males in different size groups.

Table 3: Mean G.S.I of male S. sindensis in different months.

\begin{tabular}{|c|c|c|c|c|c|}
\hline Month & $\mathrm{N}$ & $\mathrm{X}$ & S.E & \multicolumn{2}{|c|}{ C.L Min.-Max. } \\
\hline Jan. 2001 & 11 & 1.2520109 & 0.294193543 & 0.768062521 & 1.735959278 \\
\hline Feb & 11 & 0.79528 & 0.18140331 & 0.496871555 & 1.093688445 \\
\hline Mar & 05 & 1.486646 & 0.388053437 & 0.848298096 & 2.124993904 \\
\hline Apr & 09 & 1.4590088 & 0.445718075 & 0.725802566 & 2.192215033 \\
\hline May & 10 & 1.17975 & 0.24488235 & 0.776918534 & 1.582581466 \\
\hline June & 11 & 3.9798972 & 0.596789817 & 2.998177951 & 4.961616449 \\
\hline July & 20 & 3.813038 & 0.287438497 & 3.340201672 & 4.285874328 \\
\hline Aug & 09 & 4.07778333 & 0.286129163 & 3.607100827 & 4.548465773 \\
\hline Sep & 13 & 1.9989976 & 0.5486240 & 1.0346328 & 2.90148408 \\
\hline Oct & 16 & 0.8244504 & 0.168075596 & 0.547966044 & 1.100934755 \\
\hline Nov & 28 & 2.61614107 & 0.198559667 & 2.134770048 & 2.788031352 \\
\hline Dec & 16 & 0.9132275 & 0.200849545 & 0.582829998 & 1.243625002 \\
\hline Jan. 2002 & 05 & 0.6454116 & 0.332519402 & 0.107121583 & 1.201110416 \\
\hline Feb & 09 & 0.6090077 & 0.2182903 & 0.249920156 & 0.968095243 \\
\hline Mar & 18 & 0.6015588 & 0.036798171 & 0.541025808 & 0.662091791 \\
\hline Apr & 06 & 1.39494 & 0.432804268 & 0.682976979 & 2.106903021 \\
\hline
\end{tabular}

Table 4: Mean G.S.I of female S. sindensis in different months.

\begin{tabular}{cccccc}
\hline Month & $\mathrm{N}$ & $\mathrm{X}$ & $\mathrm{S} . \mathrm{E}$ & 0.627974846 & C.L Min. - Max. \\
\hline Jan. & 09 & 1.106823 & 0.287360154 & 0.165033002 & 1.573389753 \\
2001 & & & & & 2.356897197 \\
Feb & 11 & 1.2609651 & 0.66622012 & 0.849141805 & 1.653083195 \\
Mar & 07 & 1.2511125 & 0.244359085 & 1.267699684 & 2.215792716 \\
Apr & 08 & 1.7411462 & 0.288174174 & 0.797201187 & 2.432331813 \\
May & 09 & 1.614769 & 0.49700171 & 2.765032454 & 3.549817546 \\
June & 09 & 3.157425 & 0.238536502 & 3.86327535 & 5.218484465 \\
July & 20 & 4.540871 & 0.411923079 & 4.74658673 & 6.48510067 \\
Aug & 14 & 5.6158437 & 0.52842369 & 1.875208448 & 3.940151552 \\
Sep & 14 & 2.90768 & 0.627642281 & 0.761022298 & 4.823381101 \\
Oct & 23 & 1.307217 & 0.31378687 & 2.781858732 & 1.799408191 \\
Nov & 11 & 3.5331363 & 0.456703689 & 1.072828809 & 4.030367488 \\
Dec & 28 & 1.4361185 & 0.220844797 & 1.336149512 & 1.715541285 \\
Jan. & 07 & 2.6832585 & 0.818911239 & & 1.071249849 \\
2002 & & & & 0.984548114 & 3.872930941 \\
Feb & 14 & 1.3500447 & 0.222186374 & 0.60991275 & 0.651372659 \\
Mar & 18 & 0.8405813 & 0.140224042 & & \\
Apr & 18 & 2.2621518 & 0.979197046 & & \\
\hline
\end{tabular}


Table 5: mean G.S.I of males s. sindensis in different size groups

\begin{tabular}{cccccc}
\hline Size group $(\mathrm{mm})$ & $\mathrm{N}$ & $\mathrm{X}$ & $\mathrm{S} . \mathrm{E}$ & \multicolumn{2}{c}{ C.L Min - Max. } \\
\hline $100-109$ & 02 & 1.01175 & 0.4088 & 0.9445024 & 1.0789976 \\
$110-119$ & 17 & 0.7462215 & 0.052444299 & 0.659950620 & 0.83249237 \\
$120-129$ & 10 & 0.626837 & 0.018182836 & 0.596926234 & 0.65674776 \\
$130-139$ & 11 & 1.3144054 & 0.907316357 & 0.178130007 & 2.806940807 \\
$140-149$ & 29 & 2.0465934 & 0.218036186 & 1.68792387 & 2.40526292 \\
$150-159$ & 19 & 1.1018517 & 0.20299738 & 0.767921009 & 1.43578239 \\
$160-169$ & 23 & 1.6493191 & 0.427005424 & 0.946895177 & 2.351743022 \\
$170-179$ & 45 & 2.5481178 & 0.24757007 & 2.140865035 & 2.955370565 \\
$180-189$ & 32 & 2.5740809 & 0.345525857 & 2.005690865 & 3.142470935 \\
$190-199$ & 09 & 2.710506 & 0.84172282 & 1.3525774146 & 4.095237854 \\
\hline
\end{tabular}

Table 6: Mean G.S.I of females s. sindensis in different size groups

\begin{tabular}{|c|c|c|c|c|c|}
\hline Size group $(\mathrm{mm})$ & $\mathrm{N}$ & $\mathrm{X}$ & S.E & \multicolumn{2}{|c|}{ C.L Min. - Max. } \\
\hline $100-109$ & 02 & 0.918689 & 0.05162 & 0.8287651 & 0.9985949 \\
\hline $110-119$ & 14 & 1.063909 & 0.0513285 & 0.979473617 & 1.148344383 \\
\hline $120-129$ & 06 & 0.6862538 & 0.09534739 & 0.529403479 & 0.84310412 \\
\hline $130-139$ & 09 & 0.7305816 & 0.109775651 & 0.550000654 & 0.911162545 \\
\hline $140-149$ & 14 & 2.3794366 & 0.4292335909 & 1.67317903 & 3.08569417 \\
\hline $150-159$ & 21 & 2.075804 & 0.397034466 & 1.422682303 & 2.72892569 \\
\hline $160-169$ & 28 & 2.1533809 & 0.400452653 & 1.49463628 & 2.812125516 \\
\hline $170-179$ & 25 & 1.6240298 & 0.382548609 & 0.994737338 & 2.253322262 \\
\hline $180-189$ & 69 & 4.2213809 & 0.20264652 & 3.88802737 & 4.554734425 \\
\hline 190-199 & 24 & 4.549554 & 0.522374753 & 3.69024753 & 5.408060469 \\
\hline $200-209$ & 08 & 3.7692254 & 0.676884968 & 2.655749628 & 4.882701172 \\
\hline
\end{tabular}

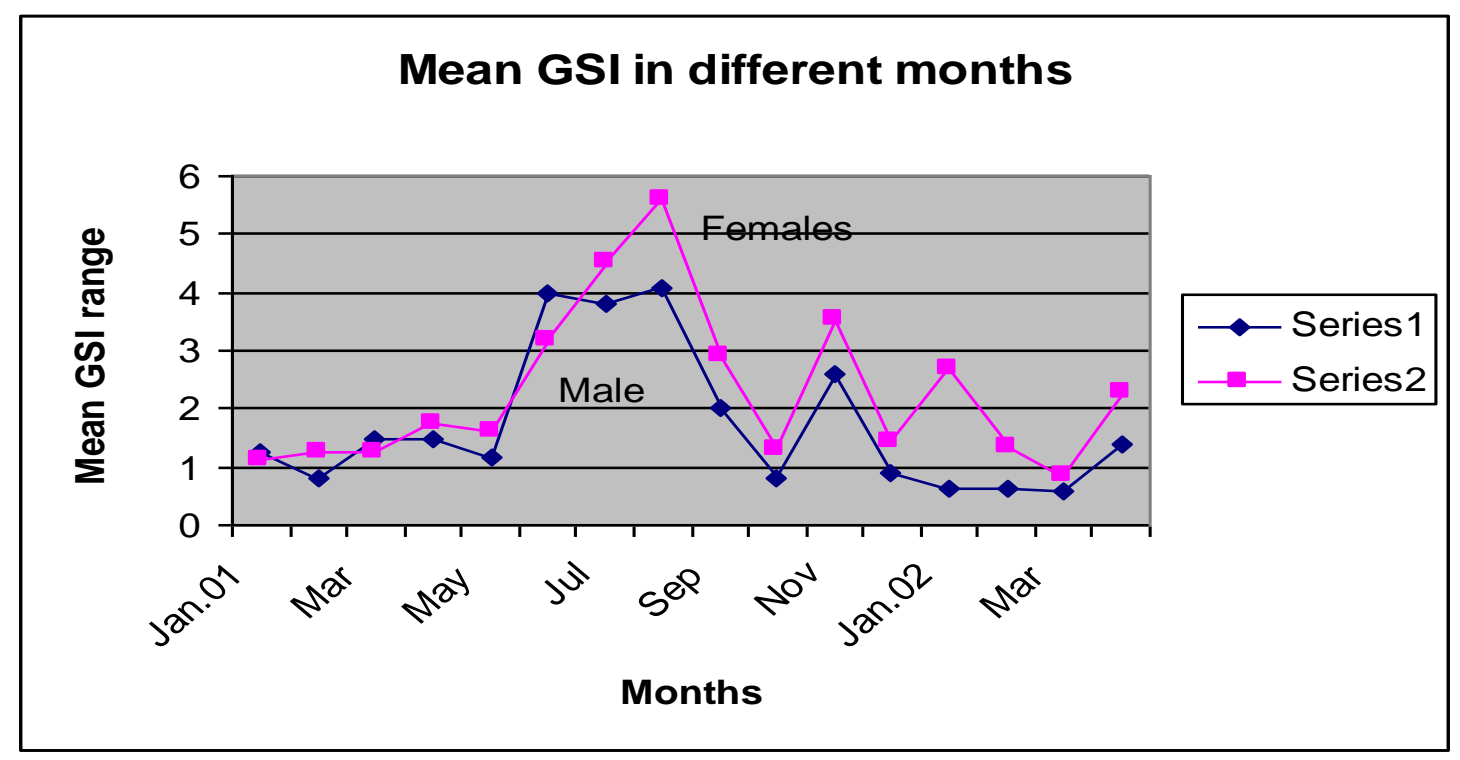

Fig. 3: Mean GSI of male \& female in different Months. 


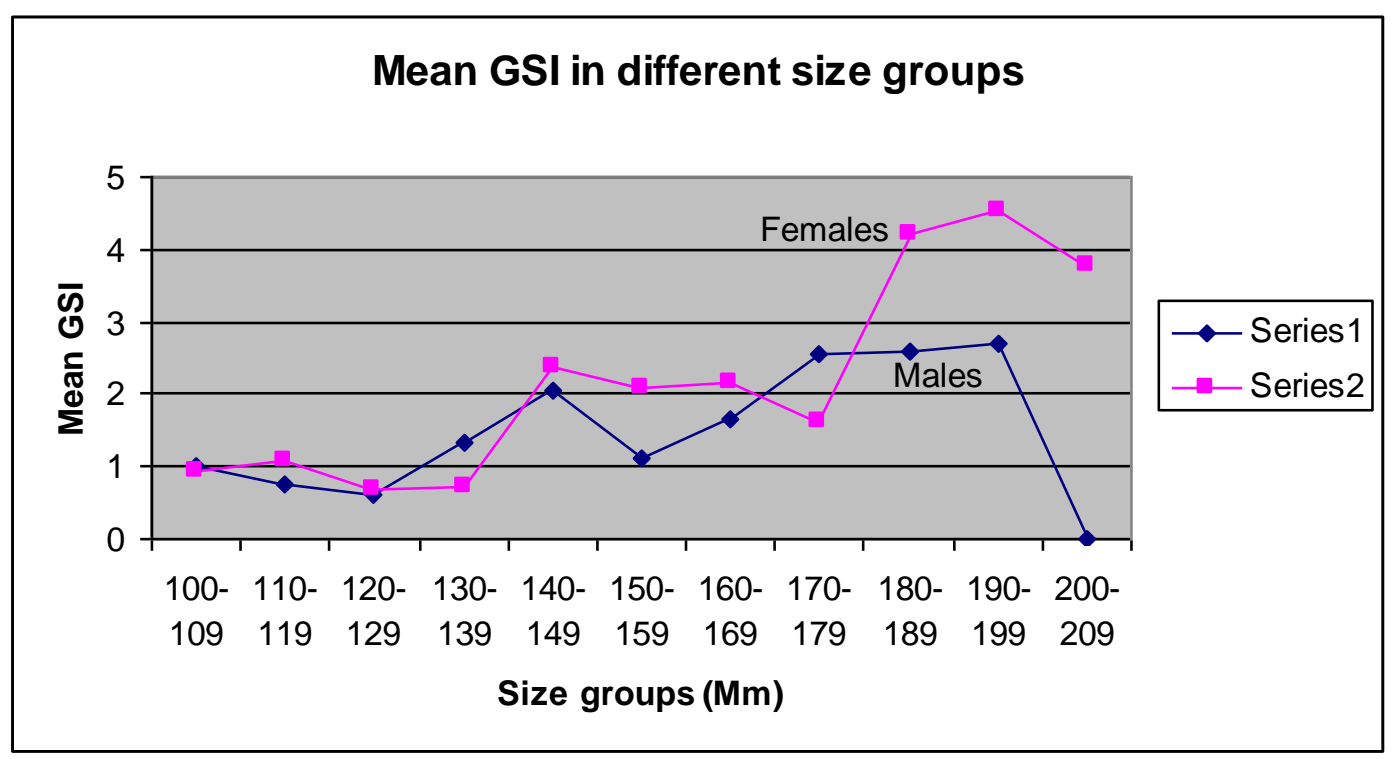

Fig. 4: Mean GSI of male \& female in different size groups (Mm).

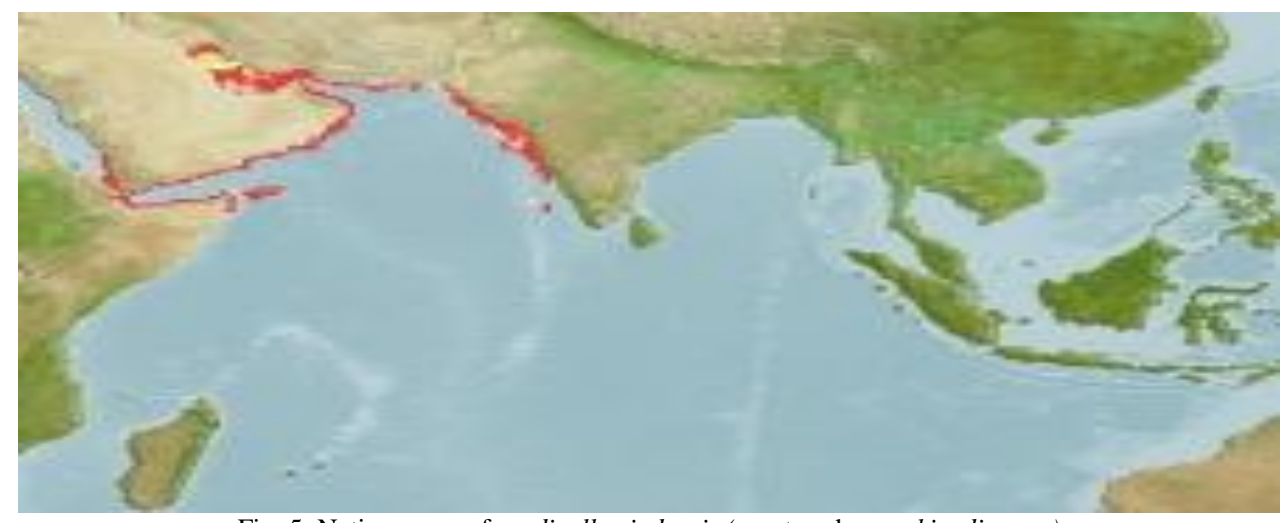

Fig. 5: Native range of sardinella sindensis (courtesy by waekipedia.com)

\section{Discussion}

The females were more than the males. However, the difference in sex ratio was not significantly different $(\mathrm{P}>0.05)$ from the expected 1: 1 distribution. Deshmukh (2010) reported the sex ratio of Sardinella longiceps off Ratnagiri coast of Maharashtra, India, which was in favour to the result obtained in this study; the females were more than the males. This is also similar to the sex ratio of Sardinella aurita recorded by Tsikliras in North-eastern Mediterranean Sea. A sex ratio of 1: 1.10 (Males to Females) was reported by Saud for the Sardinella longiceps In the Al-Seeb area of Oman, There were more females than male fish in the population, which was similar to the sex ratio of Sardinella sindensis observed in this study from Karachi coast, Pakistan.

High gonadosomatic indices were recorded for both male and female Sardinella sindensis in this study from June August, which suggested that the spawning period of Sardinella Sardinella sindensis was June to August, the peak value being in July. The gonadosomatic index of Sardinella longiceps was high in Feb - August (Saud., 2010). This was about similar to the results of the gonadosomatic index of Sardinella sindensis observed in this study. High gonadosomatic indices were recorded for Sardinella longiceps in March, april and August (Mussalam). According to [26] high GSI were recorded for Japanese sardine, Sardinops melanostictus from January to March. This was in contrast to the results obtained in this study.

This study will contribute valuable knowledge needed for fisheries management and aquaculture of Sardinella sindensis by increasing the knowledge of reproductive biology of Sardinella sindensis 


\section{Acknowledgements}

My sincere gratitude is extended to the staff members and fellow colleagues of Department of Zoology (University of Karachi) and Department of Zoology (Sir Syed Govt. Girls College, Nazimabad) and Department of Zoology, Dehli Govt. Science College, Karachi.

\section{References}

[1] HODA, S. M. S. Fishes from the coast of Pakistan. Pakistan Aquaculture. (1985). 7: 38-44.

[2] DADZIE, S. \& WANGILA, B.C.C. Reproductive biology, length-weight relationship and relative condition of pond raised Tilapia zilli (Gervais). J. Fish Biol. (1980). 17: 243-253.

[3] VICENTINI, R. N. AND ARAUJO, F. G. Sex ratio and size structure of Micropogonias furnieri (Desmarest, 1823) (Perciformes, Sciaenidae) in Sepetiba bay, Rio de Janeiro, Brazil. Braz. J. Biol. (2003). 3: 559-566.

[4] ABU-HAKIMA, R. Comparison of aspects of the reproductive biology of Pomadasys otolithes \& Pampus Sp. In Kuwaiti water. Fish. Res. (1984). 2: 177-200.

[5] ADEBIYE, F. A. The sex ratio, gonadosomatic index, stages of gonadal development and fecundity of Sompatgrunt. Pomadasys jubelini (Cuvier, 1830), Pakistan J. Zool. (2013). 45(1): 41-46.

[6] AL-GHAIS, S. M. Aspects of the biology of Pomadasys stridens (Forskaal, 1775) from the West coast of the United Arab Emirates. Arab Gulf J. Sci. Res. (1995). 13: 401- 419.

[7] AL-NAHDI, A., AL-MARZOUQI, A., JAYABALAN, N. \& AL-HABSI, S. Maturation and spawning of the small spottedgrunt Pomadasys commersonnii (Lacepede, 1801) in the Arabian Sea of Oman. Thalassas. (2010). 27: 67-79.

[8] DESHMUKH, V. M. Fishery and biology of Pomadasys hasta (Bloch). Indian Journal of fisheries. (1973). 20 (2), 497- 522.

[9] FEHRI-BEDOUI, R. AND GHARBI, H. Sex ratio, reproduction and feeding habits of Pomadasys incisus (Haemulidae) in the Gulf of Tunis (Tunisia). Acta Adriat. (2008). 49: 5-19.

[10] HODA, S. M. S. \& IQBAL, M. Some aspects of the reproductive biology of Drepane longimana (Family; Drapanidae) from Sindh coast, Pakistan Marine research. (1994). 3(2): 47-55.

[11] KHAN, M. A. \& HODA, S. M. S. Sex ratio of the sole, Euryglossa orientalis (Bal \& Schneider) (Family: Soleidae) from Karachi coast. Pakistan, Jr. Mar.Sc. (1993). 2(2): 157-159.

[12] KHAN, M. A. \& AMTYAZ. Studies on the fecundity and Sex ratio of the Saddle grunt fish Pomadasys maculatum (Bloch, 1797), (Family: Pomadasyidae) from Karachi coast. Int. J.Biol. Biotech. (2004). 1(1): 111-115.

[13] AMTYAZ, KHAN, M. A, KHAN, M. Z, \& HASHMI, M. U, A. Studies on Gonadosomatic Index \& Stages of Gonadal Development of Striped piggy fish, Pomadasys stridens (Forsskal, 1775) (Family; Pomadasyidae) of Karachi Coast, Pakistan. Journal of entomology and zoology study. (2013). 1(5): 28-31.

[14] AMTYAZ, KHAN, M. A. Studies on the Fecundity and sex ratio of striped piggy fish, Pomadasys stridens (Forsskal, 1775) (Family; Pomadasyidae) From Karachi coast, Pakistan. International Journal of biology and biotechnology. (2013). 10(3): 431-436.

[15] AMTYAZ, KHAN, M. A, KHAN, M. Z, \& HASHMI, M. U, A. Studies of the Fecundity of Sind Sardine fish, Sardinella sindensis (Day, 1878) (Family: Clupeidae), from Karachi Coast, Pakistan. Int. jour. of biological research. (2013). 1(2): 15-18.

[16] KHAN, M.A., HASHMI, M. U. A. AND YOUSUF, K. Studies on fecundity and sex ratio of Sardinella longiceps (Family: Clupeidae) from Karachi coast, Pakistan. (2005). 1(1): 435-438.

[17] MUSSALAM, A., RASHID, A. A., AL-SHUAILY, S. S. AND AMBU-ALI, A. A. Observations on the fecundity and Gonado-Somatic Index (GSI) of sardinella longiceps. Pak. Jr. Bio. Sc. (2006). 9(4): 700-702.

[18] BALAN, V. Some observation the shoaling behaviour of Oil sardine Sardinella longiceps Val. Indian J. Fish, 8(1) (1961): 206-221.

[19] DAVIES, D. H. The South African pilchard (Sardinops ocellata) determined by ova-diameter measurements. Calif.Dept. Fish and Game.Fish Bull. (1956). 42: 1-49.

[20] TSIKLIRAS, A. C. \& ANTHONOPOULOU, E. Reproductive biology of round sardinella, Sardinella aurita in the North-Eastern Mediterranean. Scientia Marina. (2006). 70(2). 281-290.

[21] DESHMUKH, A. V. KOVALE, S. R. SWANT, M. S, SHIRDHANKAR, M. M. AND FUNDE, A. B. Reproductive biology of Sardinella longiceps along Ratnagiri coast off Maharashtra. Indian Journal of Marine sciences. (2010). 39(2): 274-279.

[22] MUSTAC, B. AND SINOVCIC, G. Reproduction, length-weight and condition of Sardine, Sardina pilchardus (Walbaulm, 1792) in the eastern middle of Adriatic Sea (Croatia). Periodicum biologorum. (2010). 112(2): 133-138.

[23] WHITEHEAD, P.J.P. FAO Species Catalogue. Vol. 7. Clupeoid fishes of the world (suborder Clupeioidei). An annotated and illustrated catalogue of the herrings, sardines pilchards, sprats, shads, anchovies and wolf-herrings. FAO Fish. Synop. (1985). 125(7/1):1-303. Rome: FAO.

[24] COCHRAN, W. G. Sampling techniques. John Wiley and Sons, New York. (2007).

[25] STRUM, L. M.G. Aspects of the biology of Scombemorus maculates (Mitchill) in Trinidad. J. Fish Bio. (1978). 13: 155-172.

[26] MATSUYAMA, M. ADACHI, S. NAGAHAMA, Y. KITAJIMA, C AND MATSUURA, and S. Annual reproductive cycle of the captive female Japanese sardine, Sardinops melanostictus: relationship to ovarian development and serum levels of gonadal steroid hormones. Marine biology. (1991). 108: 21-29. 